\title{
Geometric morphometric assessment of Guanshan trilobites (Yunnan Province, China) reveals a limited diversity of palaeolenid taxa
}

\author{
Wenyu Zhao, Jianni Liu, and Russell D.C. Bicknell
}

\begin{abstract}
The Guanshan Biota is a typical Burgess Shale-type Cambrian-aged Lagerstätte with diverse trilobites. As such, the taxonomy of trilobites from the Guanshan Biota, especially the palaeolenid group, has been the focus of research over the last decade. To develop this research, we present a geometric morphometric analysis of cranidial shape in 60 specimens from three sections of the Guanshan Biota from the Wulongqing Formation (Cambrian Series 2, Stage 4), Yunnan Province, South China. We show that cranidia of Megapalaeolenus deprati and Palaeolenus douvillei occupy distinct regions of morphospaces and that $P$. douvillei and $P$. "lantenoisi" occupy the same region of morphospace. Combined with qualitative observation on the thorax, $P$. "lantenoisi" is here considered a junior synonym of $P$. douvillei. Megapalaeolenus deprati is still considered valid and is distinguished from $P$. douvillei by its rounded glabella, longer palpebral lobes, shorter ocular ridges, and more developed posterolateral projections. Its pleural spines are more curved, and pleural lobes are markedly wider than $P$. douvillei. These results highlight that the supposed diversity of palaeolenid taxa in lower Cambrian deposits need reconsideration, potentially using similar morphometric methods.
\end{abstract}

Wenyu Zhao. Early Life Institute, State Key Laboratory of Continental Dynamics, Department of Geology, Northwest University, Xi'an, Shaanxi, China. zhaowenyunwu@126.com

Jianni Liu. Early Life Institute, State Key Laboratory of Continental Dynamics, Department of Geology, Northwest University, Xi'an, Shaanxi, China. liujianni@126.com

Russell D.C. Bicknell. Palaeoscience Research Centre, School of Environmental and Rural Science, University of New England, Armidale, New South Wales, Australia, 2351. rdcbicknell@gmail.com

Keywords: Cambrian; Wulongqing Formation; South China; Guanshan Biota; palaeolenid trilobites; geometric morphometrics

Submission: 1 February 2020. Acceptance: 17 April 2020.

Zhao, Wenyu, Liu, Jianni, and Bicknell, Russell D.C. 2020. Geometric morphometric assessment of Guanshan trilobites (Yunnan Province, China) reveals a limited diversity of palaeolenid taxa. Palaeontologia Electronica, 23(2):a22. https://doi.org/10.26879/1062 palaeo-electronica.org/content/2020/3030-revision-of-cambrian-trilobite-taxa 


\section{INTRODUCTION}

Trilobite species are traditionally erected with qualitative description and observation: an approach which is informative but sometimes might be unable to derive whether specimens represent morphological extremes of one taxon or are indeed another species. This is especially the case for Cambrian trilobites that exhibit high levels of intraspecific variation that reflect taphonomic alterations, spatially segregated localities, time averaging, and ontogeny (Hughes, 1991, 1994; Webster, 2007; Esteve et al., 2017). Palaeolenids from the Guanshan Biota (Cambrian Stage 4, Series 2, Yunnan Province, South China) are one group with a complicated taxonomic history due to inter- and intra-specific variation (Table 1).

Palaeolenid trilobites from the Guanshan Biota have been arrayed across four species of two genera: Palaeolenus Mansuy, 1912 and Megapalaeolenus Chang, 1966. According to previous studies, P. longispinus Zhang and Zhu, 1980 in Chang et al., 1980 can be easily differentiated from the other three species by its very robust second thoracic tergite and hypertrophied spines on the second thoracic tergite. Palaeolenus "lantenoisi" Mansuy, 1912 has been characterized by subparallel axial glabellar furrows, broader ocular ridges and, a longer preglabellar field and 13 thoracic tergites (Luo et al., 2007; Hu et al., 2013). Palaeolenus douvillei Mansuy, 1912 has been characterized by a more rounded glabella that is expanded in the anterior region, narrower ocular ridges, a shorter preglabellar field, and more than 14 thoracic tergites (Mansuy, 1912; Luo et al., 2007; Hu et al., 2013). Megapalaeolenus deprati Mansuy, 1912 has been characterized by a larger body, a more rounded glabella that is expanded in the anterior region, narrower ocular ridges, longer palpebral lobes, and 14 to 15 thoracic tergites (Luo et al., 2007, 2014; Hu et al., 2013). In sum, the characters used to differentiate these species are primarily on cranidial shape, with the exception of the hypertrophied spines of $P$. longispinus.

Studies over the last 20 years have considered whether Megapalaeolenus deprati and Palaeolenus douvillei were conspecific (Lin and Peng, 2004, 2009, 2016; Luo et al., 2007, 2014; Hu et al., 2013; Lin, 2014) using qualitative observation and traditional morphometric analyses of cranidial shapes. The validity of the genera has caused complications as the Wulongqing Formation, which contains the Guanshan Biota, was traditionally divided into two trilobite zones: the lower Palaeolenus Zone and the upper Megapalaeolenus Zone (Luo et al., 2008; Hu et al., 2013, 2017), and these

TABLE 1. Taxonomic study history of palaeolenid trilobites from the Guanshan Biota.

\begin{tabular}{|c|c|c|}
\hline Publication & Species considered & Relevant notes \\
\hline Mansuy (1912, p. 27) & $\begin{array}{l}\text { Palaeolenus douvillei, P. deprati and } \\
\text { P. "lantenoisi" }\end{array}$ & $\begin{array}{l}\text { First description of three Palaeolenus species using a few } \\
\text { specimens }(n=6) \text { with all the cranidial features exhibiting }\end{array}$ \\
\hline Chang (1966, p. 150). & Megapalaeolenus deprati & Moved Palaeolenus deprati into Megapalaeolenus \\
\hline $\begin{array}{l}\text { Chang et al. (1980, p. } \\
234 \text {, pl. } 73 \text {, figs 9-12) }\end{array}$ & Palaeolenus longispinus & $\begin{array}{l}\text { Erected Palaeolenus longispinus using robust pleural spines on } \\
\text { second thoracic tergite }\end{array}$ \\
\hline Lin and Peng (2004) & $\begin{array}{l}\text { Megapalaeolenus deprati and } \\
\text { Palaeolenus douvillei }\end{array}$ & $\begin{array}{l}\text { Doubted the validity of Megapalaeolenus. Noted that holotype was } \\
\text { deformed and considered } M \text {. deprati conspecific with Palaeolenus } \\
\text { douvillei }\end{array}$ \\
\hline Luo et al. (2007) & $\begin{array}{l}\text { Megapalaeolenus deprati, } \\
\text { Palaeolenus douvillei and } P \text {. } \\
\text { "lantenoisi" }\end{array}$ & Considered all species and genera to be valid \\
\hline Lin and Peng (2009) & $\begin{array}{l}\text { Megapalaeolenus deprati and } \\
\text { Palaeolenus douvillei }\end{array}$ & Considered species conspecific \\
\hline Hu et al. (2013) & $\begin{array}{l}\text { Megapalaeolenus deprati, } \\
\text { Palaeolenus douvillei, P. "lantenoisi" } \\
\text { and P. longispinus }\end{array}$ & Suggested all taxa were valid species \\
\hline Lin (2014) & $\begin{array}{l}\text { All the published } 34 \text { specimens } \\
\text { assigned to palaeolenids }(n=34)\end{array}$ & $\begin{array}{l}\text { Used cluster analysis to group all taxa into Palaeolenus. } \\
\text { Suggested } P \text {. douvillei and Megapalaeolenus deprati conspecific }\end{array}$ \\
\hline Luo et al. (2014) & $\begin{array}{l}\text { Palaeolenus douvillei and } \\
\text { Megapalaeolenus deprati }\end{array}$ & $\begin{array}{l}\text { Considered both taxa valid. Noted they are found in different } \\
\text { members of the Wulongqing Formation }\end{array}$ \\
\hline Lin and Peng (2016) & $\begin{array}{l}\text { All the published } 34 \text { specimens } \\
\text { assigned to palaeolenids }(n=34)\end{array}$ & $\begin{array}{l}\text { Used cluster analysis to group. Reconfirmed Lin (2014), } \\
\text { suggesting Palaeolenus douvillei and Megapalaeolenus deprati } \\
\text { are conspecific }\end{array}$ \\
\hline
\end{tabular}


zones have been considered uninformative in the light of possible synonymy of the genera (Lin and Peng, 2004, 2009, 2016). It is, therefore, imperative to ascertain if the two genera are synonymous. Further complications are present within the palaeolenids of the Guanshan Biota as the validity of $P$. douvillei and $P$. "lantenoisi" has been debated: authors have suggested that they were unable to confidently differentiate $P$. "lantenoisi" and P. douvillei when thoracic tergites numbers are not definitive (Hu et al., 2013). Conversely, P. longispinus is likely a valid taxon as there are a robust second thoracic tergite and hypertrophied spines on meraspid and holaspid specimens (Laibl et al., 2015). To this end, while $P$. longispinus is accounted for, M. deprati, $P$. douvillei, and $P$. "lantenoisi" need to be explored.

Geometric morphometric analyses are powerful tools for assessing morphology (MacLeod, 2001, 2002; Webster and Sheets, 2010; Crônier et al., 2015; Webster, 2015; Pates et al., 2017; Monti, 2018; Bicknell, 2019; Bicknell and Pates, 2019; Bicknell et al., 2018, 2019b) and can be more informative than traditional morphometrics (Zelditch et al., 2004; Aytekin et al., 2007). Landmark-based morphometrics have been effectively used to differentiate inter- and intra-specific variation in trilobites (e.g., Hopkins and Webster, 2009; Webster, 2011; Abe and Lieberman, 2012; Gendry et al., 2013; Esteve et al., 2017; Bicknell et al., 2019a) and semi-landmarks of cranidial shape allow taxonomically useful shapes to be thoroughly assessed. Here we use landmark and semi-landmark geometric morphometrics to explore cranidial shape in Megapalaeolenus deprati, Palaeolenus "Iantenoisi," and P. douvillei and combine these results with the qualitative observation in thorax to suggest that only two taxa are valid.

\section{GEOLOGICAL SETTING}

The Guanshan Biota are preserved in the Wulongqing Formation (Cambrian Series 2, Stage 4; Figure 1) and are therefore slightly younger than the Chengjiang Biota (Cambrian Series 2, Stage 3) (Hu et al., 2010, 2013, 2017; Liu et al., 2012, 2016; Ding et al., 2020). The palaeolenid trilobites studied here were collected from three sections of the Wulongqing Formation: the Huanglongqing, Longbaoshan, and Xinglongcun sections. The Huanglongqing Section (Figure 1B; HLQ specimens) is located at the entrance door of the "Huanglongqing Hotel" (N25 $5^{\prime} 20^{\prime \prime}$ E102 $48^{\prime} 14$ "). Approximately 6 $\mathrm{m}$ of the Wulongqing Formation is exposed here, and the presence of Redlichia mai Lu, 1941 sug- gests that the section probably represents an interval within the upper Wulongqing Formation ( $\mathrm{Hu}$ et al., 2013; Figure 1A). Lower section is dark-grey, laminar, and with organic rich silty mudstones, and the upper section is a grey-green laminar silty mudstone. The Longbaoshan Section (Figure 1C; LBS specimens) is located along the Longbaoshan Mountain, ca. $1.4 \mathrm{~km}$ from Gaoloufang Village, Guandu County. The Wulongqing Formation exposed at this section is ca. $30 \mathrm{~m}$ thick, and the lower-middle Wulongqing Formation is preserved above the Hongjingshao Formation. The Wulongqing Formation here consists of yellow-green mudstones with siltstone interbeds. The Xinglongcun Section (Figure 1D; XLC specimens) is located along a mountain in Xinglong Village, northeast Wuding County. The section contains ca. $3 \mathrm{~m}$ of the Hongjingshao Formation and ca. $10 \mathrm{~m}$ of the lower-middle Wulongqing Formation. The Wulongqing Formation outcrops here as grey-yellow mudstones with siltstone interbeds (Liu et al., 2016).

\section{MATERIAL AND METHODS}

The geometric morphometric analysis was conducted on palaeolenid specimens that were not tectonically deformed and had at least half a cranidium preserved. As such, 60 palaeolenids, originally identified as Palaeolenus douvillei, $P$. "lantenoisi" and Megapalaeolenus deprati, were analyzed. A total of 37 palaeolenid trilobites assigned to Palaeolenus douvillei or P. "lantenoisi" from the Gaoloufang Section, 15 assigned to $P$. douvillei or $P$. "lantenoisi" from the Xinglongcun Section and eight assigned to $M$. deprati from the Huanglongqing Section. All specimens are housed at the Early Life Institute, Northwest University, Xi'an, China.

Specimens were photographed with a Canon EOS 5D Mk. IV camera under normal light. These photographs were used for landmarking and semilandmarking. Landmarking and semilandmarking was conducted using the Thin-Plate Spline (TPS) suite of software (http://life.bio.sunysb.edu/morph/ index.html). A TPS file was constructed using tpsUtil64 (v.1.7). The TPS file was imported into tpsDig2 (v.2.26). The $x y$ coordinates were recorded for eight homologous landmarks and two curves: one curve with 30 points around the margin of the glabellar and a second curve with 50 points along the cranidial margin (Figure 2; Appendix 1). The curves were digitised in a clockwise direction. The semilandmarks were computationally adjusted into sliding semilandmarks by using the minimization of 
A

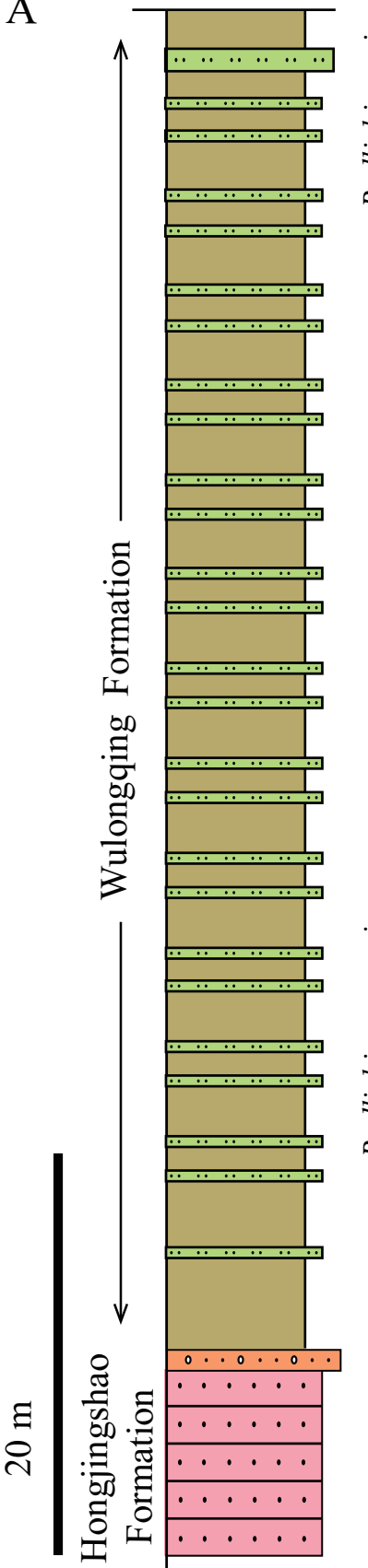

E

$\mathrm{B}$

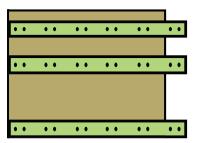

$\mathrm{C}$

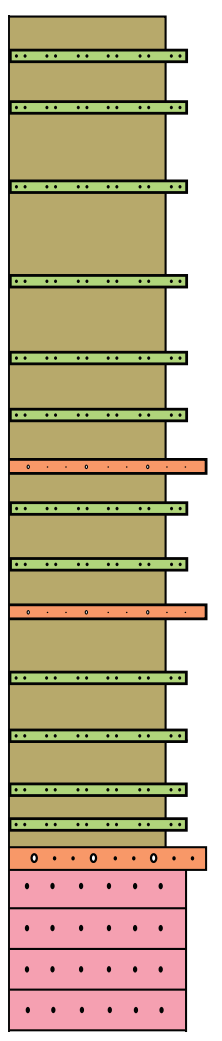

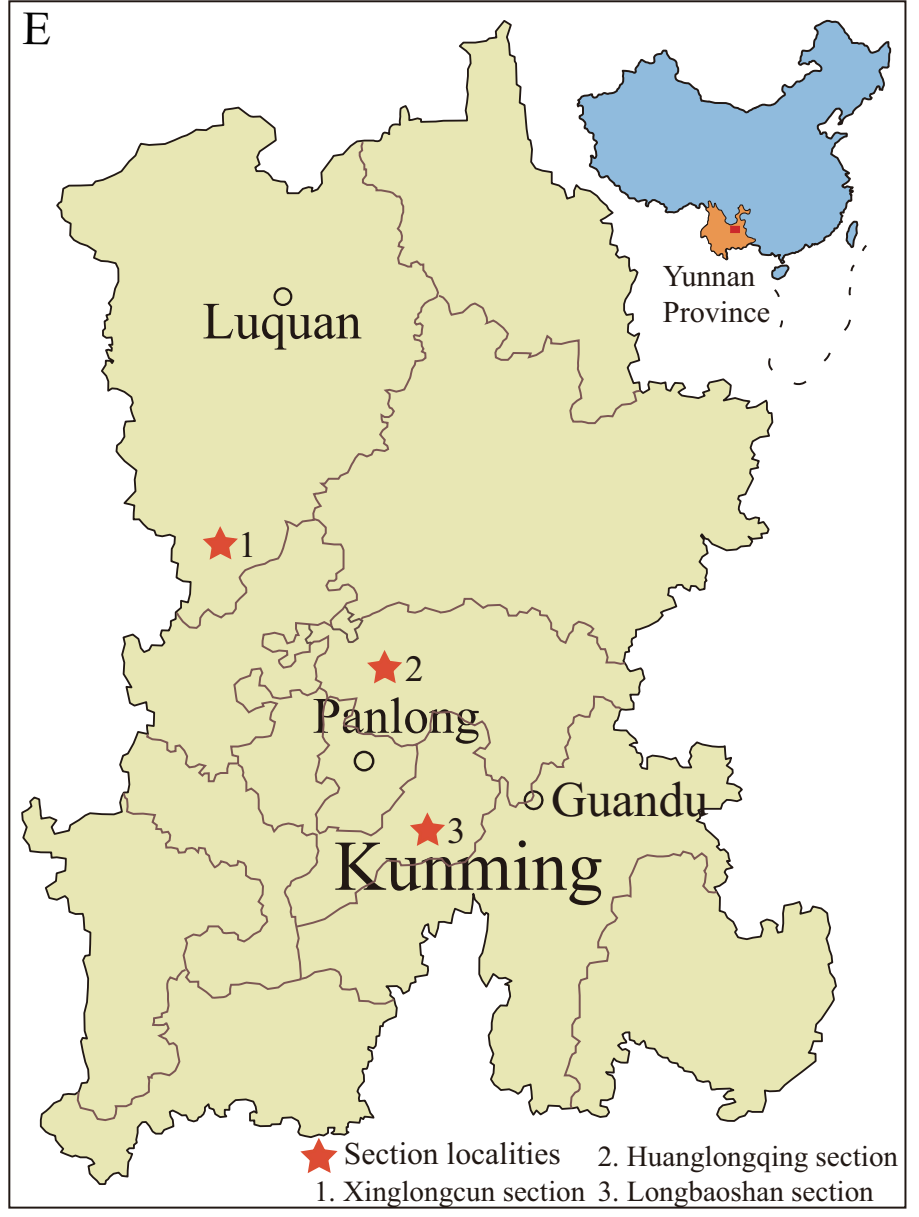

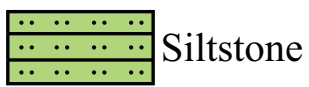

$\mathrm{D}$

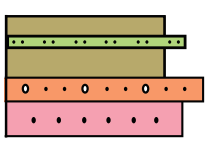

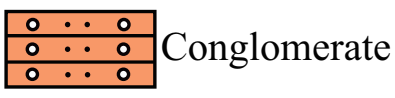

Mudstone

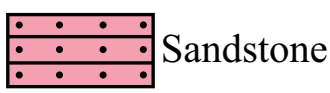

FIGURE 1. Geological and biostratigraphical maps. A. The Shitangshan Section showing approximate stratigraphic distribution of Redlichia mansuyi and Redlichia mai (modified from Hu et al. 2010). B-D. Studied sections showing their approximate stratigraphic levels respectively in Wulongqing Formation. B. Huanglongqing Section. C. Longbaoshan Section. D. Xinglongcun Section. E. Map of Kunming showing the localities of studied sections. The red lines with arrows showing approximate sampling interbeds in each section.

Procrustes distance prior to analysis (Adams and Otárola-Castillo, 2013). Semilandmarks summarize the curvature of the perimeter of cranidial features (Webster and Sheets, 2010), and landmarks combined semilandmarks summarize the overall cranidial shape (Hopkins and Webster, 2009;
Esteve et al., 2017). An explanation of the landmarks is presented in Table 2. Curves and landmarks were placed preferentially on the right cephalic side (Figure 2). When the right side was damaged, the left side was digitised. The resulting TPS file was imported into the $\mathrm{R}$ environment. For 


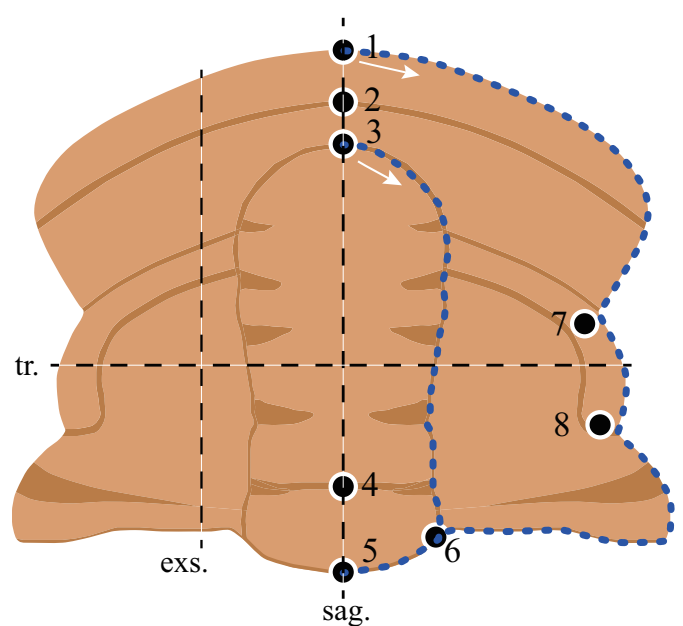

FIGURE 2. Reconstruction of the Palaeolenus douvilei cephalon showing chosen landmarks and semilandmarks. Blue outlines show semilandmarks placement. White arrows indicate semilandmarks trajectory. The black lines show the orientations which are following Whittington et al. (1997). Abbreviations: sag. - sagittal; tr. - transverse; exs. - exsagittal.

specimens that had the left side digitised, the landmark and semilandmark data were mirrored in $\mathrm{R}$. The 'geomorph' package (Adams and Otárola-Castillo, 2013) conducted a Procrustes Superposition and Principal Components Analysis (PCA) of superimposed data (following Webster and Hughes, 1999; Wester and Sheets, 2010). Procrustes tangent coordinates were plotted against logged-centroid size values to explore patterns in specimen size. Finally, statistically significant differences between the mean shape of the major groups of specimens (discussed in System-

TABLE 2. Locations of cephalic landmarks for analyzed specimens.

\begin{tabular}{|c|c|}
\hline Landmark & Description \\
\hline 1 & $\begin{array}{l}\text { Intersection of anterior border with sagittal } \\
\text { line }\end{array}$ \\
\hline 2 & Intersection of border furrow with sagittal line \\
\hline 3 & $\begin{array}{l}\text { Intersection of anterior margin of frontal lobe } \\
\text { with sagittal line }\end{array}$ \\
\hline 4 & $\begin{array}{l}\text { Intersection of anterior margin of occipital } \\
\text { ring with sagittal line }\end{array}$ \\
\hline 5 & $\begin{array}{l}\text { Intersection of posterior margin of occipital } \\
\text { ring with sagittal line }\end{array}$ \\
\hline 6 & $\begin{array}{l}\text { Intersection of axial glabellar furrow and } \\
\text { posterior margin }\end{array}$ \\
\hline 7 & Anterior border of palpebral lobe \\
\hline 8 & Posterior border of palpebral lobe \\
\hline
\end{tabular}

atic Palaeontology) were explored with a Procrustes ANOVA following Bicknell et al. (2019a). Here the ANOVA groupings were the two sites where the different genera were found: the Huanglongqing section and the Longbaoshan and Xinglongcun sections. The Principal Component (PC) data were plotted and colour coded by sections as we were unable to confidently assign select specimens to either Palaeolenus douvillei or P. "lantenoisi (Appendix 2). This uncertainty reflected that preservation of just the cranidia or the lack of all thoracic tergites. Additionally, sagittal body length measurements were taken for complete specimens to further assess the relationship between body length and thoracic tergite count (Appendix 2). Note that complete here refers to those specimens that have an articulated cephalon, thorax, and pygidium.

\section{RESULTS}

Principal Component (PC) 1 explains 42.1\% of the variance and shows groups that were split mostly with fixigena and glabella variation (Figure $3 \mathrm{~A}, \mathrm{C})$. Furthermore, posterolateral projection, glabella shape, palpebral lobe length, relative length of preglabellar field, and anterior border all vary along this axis. More positive PC1 values $(-0.0321$ to 0.07481 ) contain specimens from the Longbaoshan and Xinglongcun sections and more negative PC1 values (<-0.0377) contain specimens from the Huanglongqing Section. Negative scores along PC1 are associated with a more convex and broader (tr.) glabella, longer (exs.) palpebral lobes, a narrower (tr.) fixigena field, a shorter (sag.), but wider (tr.) posterolateral projection, and an anterior border that is longer (sag.) than the preglabellar field. More positive scores along PC1 are associated with a narrower (tr.) glabella, concave in the middle axial glabellar furrow, shorter (exs.) palpebral lobes, and an anterior border that is shorter (sag.) than the preglabellar field.

PC2 explains $18.05 \%$ of the variance and reflects the shape of the preocular area, glabella shape, posterolateral projection, anterior and posterior facial suture branches, and orientation of the palpebral lobes. Positive PC2 scores are associated with a shorter anterior facial suture branch, wider (tr.) posterolateral projection, and a more rounded glabella. Negative scores along PC2 are associated with a longer anterior facial suture branch, palpebral lobes that are subparallel to the axial glabellar furrow, a narrower (tr.) posterolateral projection, and a narrower (tr.) glabella. Specimens 


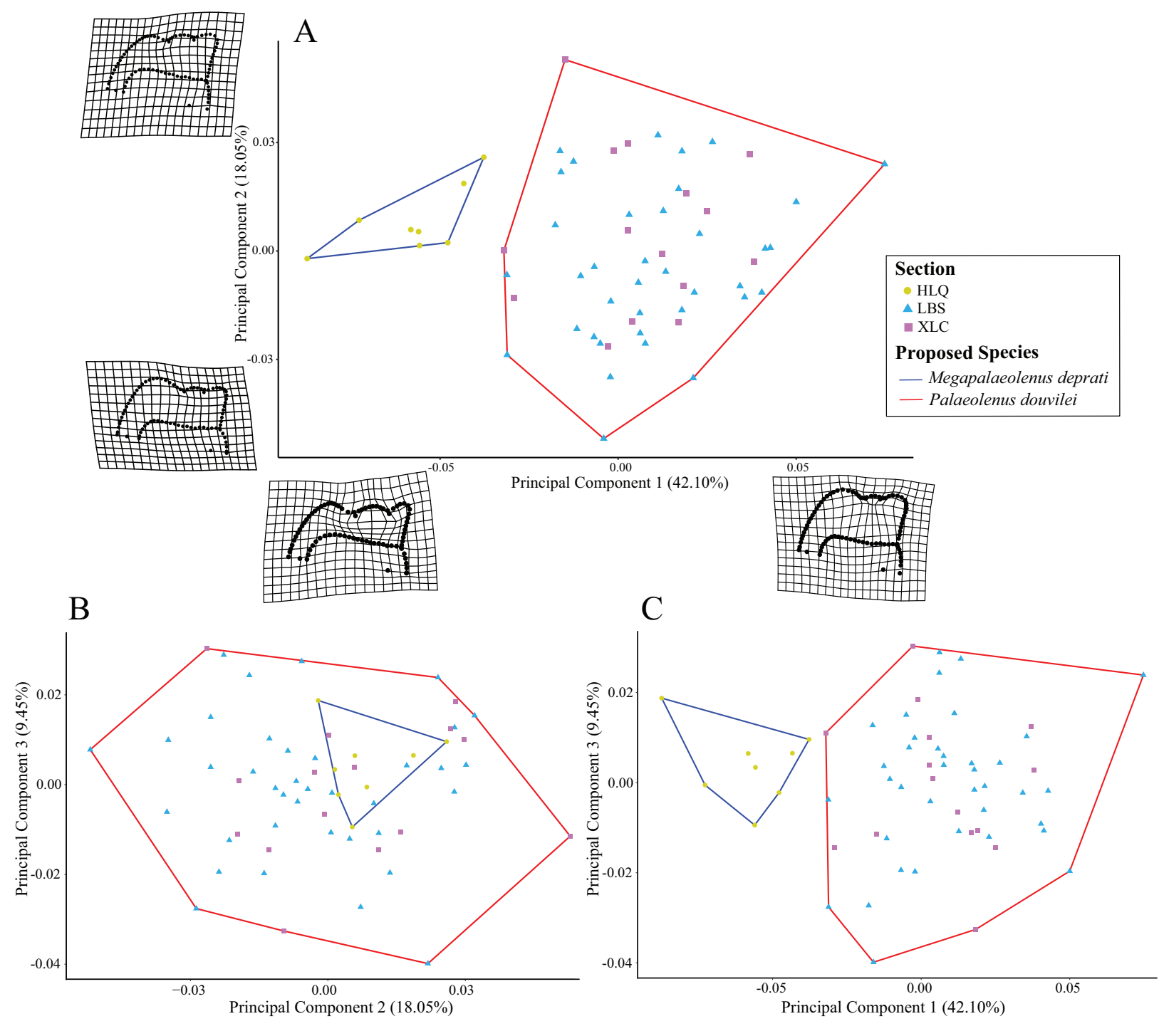

FIGURE 3. Plots of principal component analyses. A. Plot of PC1-PC2 space where two main clusters are identified. Cluster in more positive PC1 space contains Palaeolenus douvillei specimens and the cluster in more negative PC1 space contains Megapalaeolenus deprati specimens. Thin-plate spline indicates the extreme shape for each axis. $\mathbf{B}$. Plot of PC2-PC3 space showing no distinct clusters. C. Plot of PC1-PC3 space showing two distinct clusters of the $P$. douvillei and $M$. deprati. Clusters are all bound by convex hulls of proposed taxa.

from the three localities exhibit similar scores along this axis.

PC3 explains $9.45 \%$ of the variance and relates to the shape of preglabellar field, posterolateral projection, and preocular area. Positive PC3 scores are associated with a longer (sag.) preglabellar field, a rounder preocular area, and a rounder posterolateral projection. Negative scores along PC3 are associated with a shorter (sag.) preglabellar field, a relatively more convex preocular area, and a relatively more convex posterolateral projection. Specimens from the three localities exhibit similar scores along this axis, and there is substantial overlap of all specimens in the PC2PC3 plot (Figure 3B).

Results of the Procrustes ANOVA ( $F=$ 17.657, $p=0.001$, iterations $=999$ ) show that there is very significant difference between the specimens in the Longbaoshan and Xinglongcun sections and those specimens in the Huanglongqing Section. Plotting log-centroid size against regressed Procrustes ANOVA scores (Figure 4) shows that larger specimens are from the Huanglongqing section while specimens from in the Longbaoshan and Xinglongcun sections are 


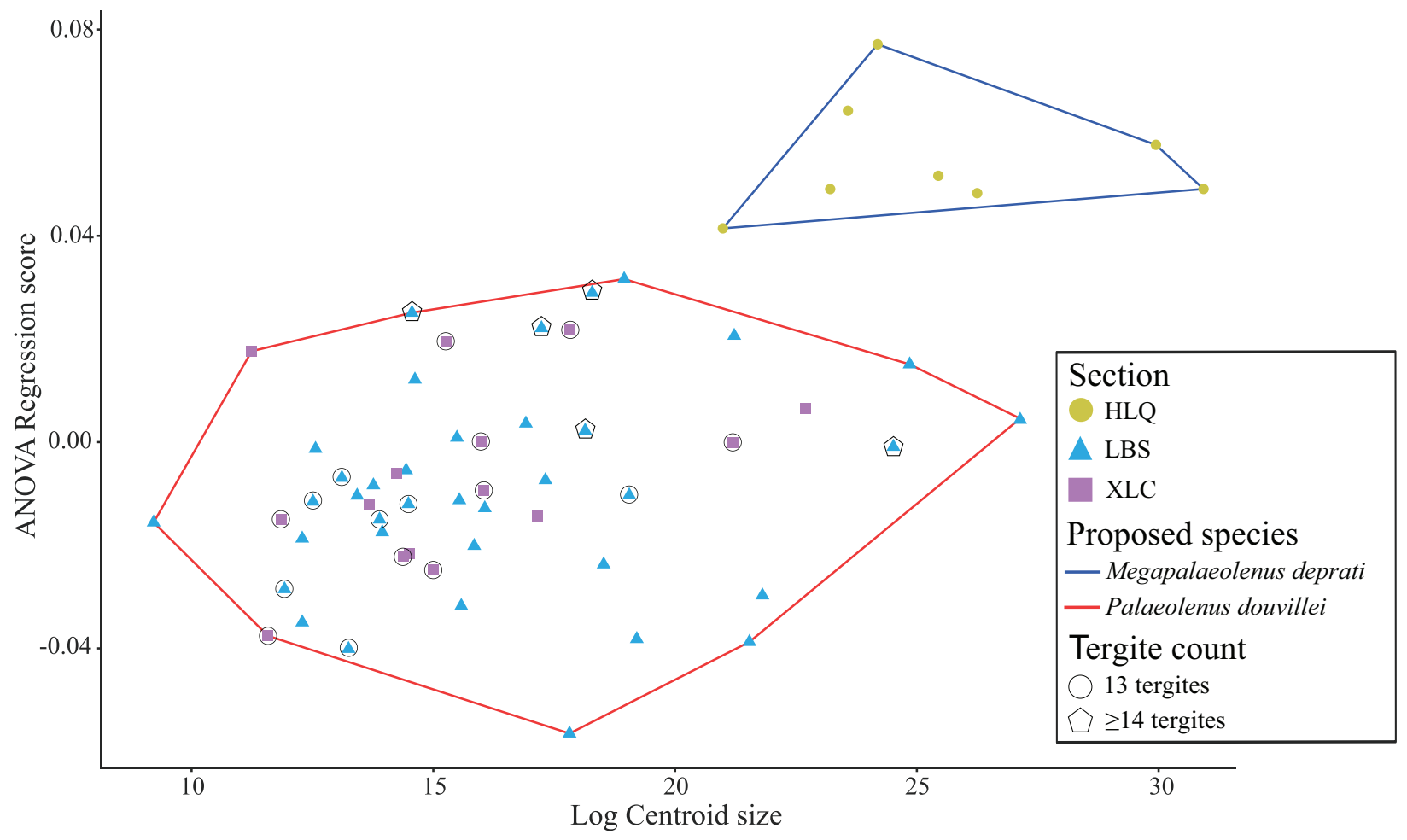

FIGURE 4. The log-centroid size against regressed Procrustes ANOVA scores plot indicates the distinct clusters of the Palaeolenus douvillei and Megapalaeolenus deprati. Clusters bound by convex hulls of taxa. Hollow circles around points indicate specimens with 13 tergites and hollow pentagons around points indicate specimens with at least 14 tergites.

smaller and still located in a different bivariate space as the Figure 3A (PC1 and 2).

\section{DISCUSSION}

In previous studies, Palaeolenus "lantenoisi" is considered to have subparallel axial glabellar furrows, broader (tr.) ocular ridges, a longer (sag.) preglabellar field, and 13 thoracic tergites (Luo et al., 2007; Hu et al., 2013). Palaeolenus douvillei is described as having a more rounded glabella, which is expanded in the anterior region, narrower (tr.) ocular ridges, a shorter (sag.) preglabellar field, and 14 or 15 thoracic tergites (Mansuy, 1912; Luo et al., 2007; Hu et al., 2013). The PCA conducted here illustrates the palaeolenid specimens from the Longbaoshan and Xinglongcun sections-taxa assigned to $P$. "lantenoisi" and $P$. douvillei-occupy the same region of cranidial morphospace, which suggests that their similarities in cranidia. Another major difference between $P$. douvillei and $P$. "lantenoisi" was the number of thoracic tergites. However, Hu et al., 2013 noted they were unable to confidently differentiate $P$. "Iantenoisi" and $P$. douvillei when thoracic tergites numbers are not easily differentiated. We have also observed this condition in the sampled specimens. There are 21 specimens analyzed herein with 13,14, and 15 tergites. We therefore coded Figure 4 for specimens with 13 tergites and those with at least 14 tergites. The results also show that, in bivariate space, both groups overlap. When sizes are considered, specimens with 13 thoracic tergites vary between 8.05 and $15.79 \mathrm{~mm}$ long, while the two specimens with 15 thoracic tergites are $13.65 \mathrm{~mm}$ and $19.45 \mathrm{~mm}$ long. Additionally, the majority (76\%) of the complete specimens have 13 thoracic tergites. Taken together, this evidence suggests that the number of thoracic tergites in holaspid $P$. douvillei specimens may have varied (sensu Hughes et al., 1999, 2017; Fusco et al., 2004). However, a detailed study outlining the mechanism and indeed pattern of ontogenetic developmental requires a much larger sample size and was beyond the initial scope of our study. The occupation of the same cranidial morphospace, coupled with little other morphological variation, suggests that diagnostic features of $P$. "lantenoisi" represent intraspecific variation. Palaeolenus "lantenoisi" is therefore a junior synonym of $P$. douvillei. 

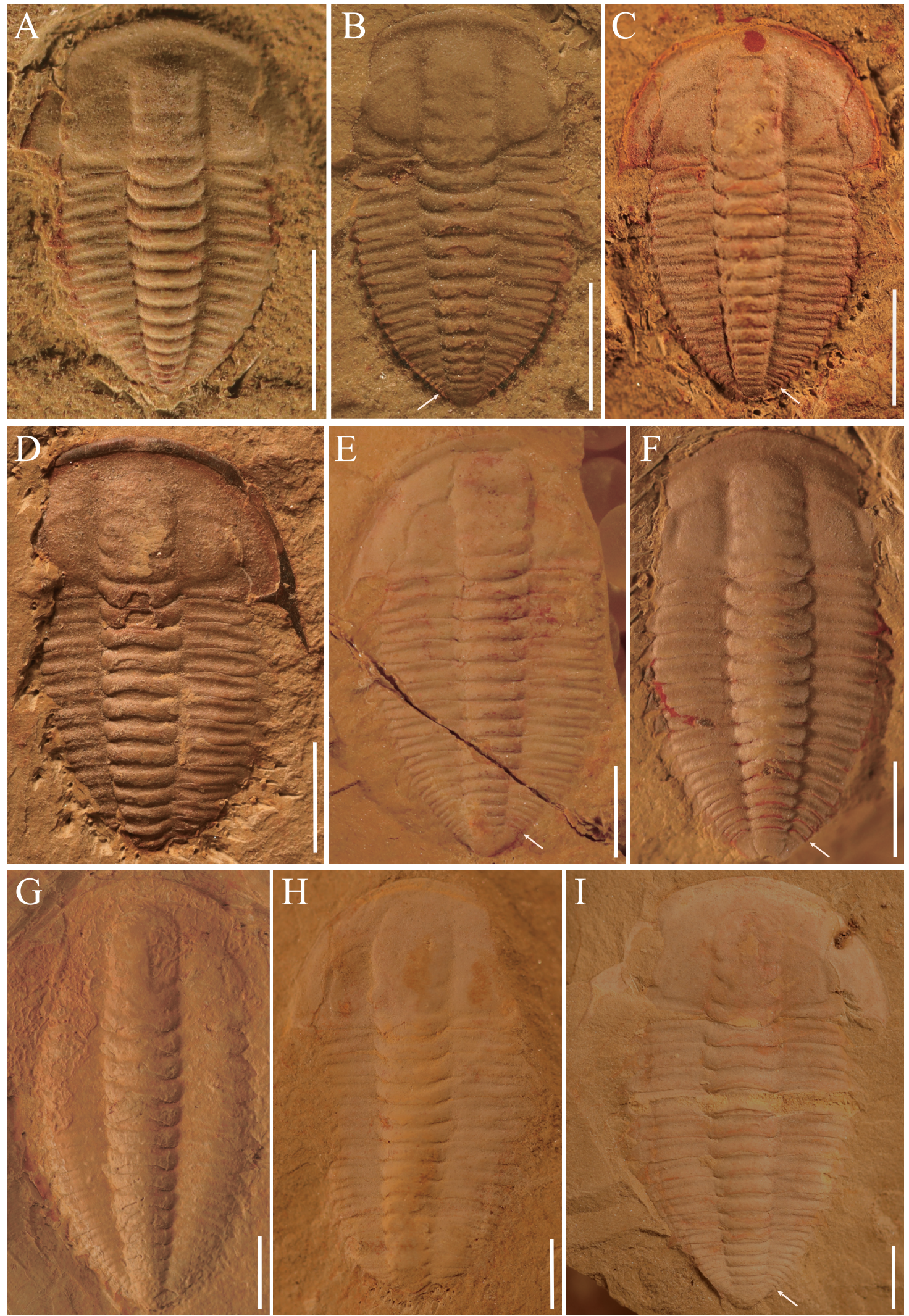

FIGURE 5. Articulated specimens of Palaeolenus douvillei from the Longbaoshan and Xinglongcun sections. A. LBS548. B. XLC-1960. C. LBS-566. D. XLC-2000A. E. LBS-661A. F. LBS-151. G. XLC-0904. H. LBS-629. I. LBS-177. Scale bars equal $3 \mathrm{~mm}$. White arrows indicate the thorax-pygidium boundary. 
The other distinct feature of the PC plots is that Huanglongqing Section specimens (=Megapalaeolenus deprati) occupy a distinct region of cranidial morphospace from the other specimens. The distinct separation of these specimens from Palaeolenus specimens along PC1 supports the suggestion of Luo et al. $(2007,2008,2014)$ that M. deprati is a valid genus and species. This separation in PC space also shows that $M$. deprati is distinct from $P$. douvillei (sensu Park et al., 2008). Apart from the shape differences in cranidia, pleural spines of $M$. deprati are more curved than that of $P$. douvillei, and pleural lobe of $M$. deprati is pronouncedly wider (tr.) than axial lobe while pleural lobe of $P$. douvillei is slightly wider (tr.) than axial lobe.

\section{SYSTEMATIC PALAEONTOLOGY}

Family PALAEOLENIDAE Hupé, 1952

Genus PALAEOLENUS Mansuy, 1912

Type species. Palaeolenus douvillei Mansuy, 1912 by original designation.

Included species. Palaeolenus douvillei Mansuy, 1912, Palaeolenus longispinus Zhang et Zhu, 1980

Palaeolenus douvillei Mansuy, 1912 Figure 5

1912 Palaeolenus douvillei Mansuy. Mansuy, p. 29, pl. 3, fig. 6a-d; pl. 4, fig. 1a-d.

1912 Palaeolenus lantenoisi Mansuy. Mansuy, p. 29, pl. 4, fig. 2a-e.

1941 Palaeolenus douvillei Mansuy. Lu, p.83, pl. 1, fig. 14.

1941 Palaeolenus tingi Lu. Lu, p.83, pl. 1, fig. 15 a-b.

1941 Palaeolenus lantenoisi Mansuy. Lu, p.84, pl. 1, fig. 13a-c.

1965 Palaeolenus douvillei Mansuy. Lu, Chang, Chu, Chien, and Hsiang., p. 82, pl. 12, fig. 9.

1965 Palaeolenus lantenoisi Mansuy. Lu, Chang, Chu, Chien, and Hsiang., p. 83, pl. 12, figs. 11, 12.

1965 Palaeolenus tingi Lu. Lu, Chang, Chu, Chien, and Hsiang, p. 84, pl. 12, figs. 13

1978 Palaeolenus lantenoisi Mansuy. Zhou and Lin, p. 149 , pl. 24, figs. 7-9.

1980 Palaeolenus tingi Lu. Chang, Lu, Chu, Chien, Lin, Zhou, Zhang, and Yuan., p. 231, pl. 71, figs. 4-6.

1980 Palaeolenus lantenoisi Mansuy. Chang, Lu, Chu, Chien, Lin, Zhou, Zhang, and Yuan, p. 230, pl. 71, figs. 1-3; pl. 72, fig. 1.

1988 Palaeolenus lantenoisi Mansuy. Yi, p. 31, pl. 1, figs. 1-18.

2004 Palaeolenus douvillei Mansuy. Lin and Peng, p. 35, pl. 1, figs. 1-15; pl. 2, fig. 3.
2008 Palaeolenus douvillei Mansuy. Luo, Li, Hu, Fu, Hou, Liu, Chen, Li, Pang, and Liu, p. 74, pl. 18, figs. 1-4.

2008 Palaeolenus lantenoisi Mansuy. Luo, Li, Hu, Fu, Hou, Liu, Chen, Li, Pang, and Liu, p. 75, pl. 18, figs. 7-16.

2013 Palaeolenus douvillei Mansuy. Hu, Zhu, Luo, Steiner, Zhao, Li, Liu, and Zhang, p. 96, figs. 120, 121.

2013 Palaeolenus lantenoisi Mansuy. Hu, Zhu, Luo, Steiner, Zhao, Li, Liu, and Zhang, p. 96, figs. $122,123 \mathrm{~A}-\mathrm{N}$.

Referred material. LBS-5, LBS-113, LBS-116, LBS-121, LBS-123, LBS-125, LBS-126, LBS-129, LBS-130, LBS-131, LBS-132, LBS-135, LBS-139, LBS-140, LBS-141, LBS-142, LBS-145, LBS-151, LBS-154, LBS-155, LBS-160, LBS-177, LBS-185, LBS-187, LBS-216, LBS-217, LBS-224, LBS-267, LBS-301, LBS-306, LBS-310, LBS-312, LBS-313, LBS-315, LBS-319, LBS-321, LBS-325, LBS-381, LBS-394, LBS-397, LBS-399, LBS-401, LBS-405, LBS-408, LBS-410, LBS-411, LBS-413, LBS-417, LBS-422, LBS-427, LBS-437, LBS-440, LBS-444, LBS-454, LBS-459, LBS-461, LBS-472, LBS-474, LBS-517, LBS-523, LBS-524, LBS-528, LBS-531, LBS-548, LBS-549, LBS-553, LBS-556, LBS-561, LBS-566, LBS-567, LBS-603, LBS-617, LBS-626, LBS-629, LBS-661, LBS-669, LBS-688, LBS-690, LBS-718, XLC- 0021, XLC-0028, XLC-0407, XLC0427, XLC-0904, XLC-0915, XLC-0936, XLC0977, XLC-0991, XLC-1000, XLC-1100, XLC-1101, XLC-1117, XLC-1124, XLC-1267, XLC-1274, XLC1276, XLC-1290, XLC-1300, XLC-1307, XLC1342, XLC-1350, XLC-1364, XLC-1434, XLC1445, XLC-1457, XLC-1827, XLC-1837, XLC1844, XLC-1855, XLC-1976, XLC-2000, XLC2001.

Diagnosis. Palaeolenus with long (tr.) ocular ridges, short (exs.) palpebral lobes, oblique to the axial furrow with a moderately robust glabella and a relatively broad (tr.) fixigena.

Description. The morphologically mature exoskeleton is ovate in outline, micropygous and $1-2 \mathrm{~cm}$ long (sag.). Cephalon is semi-elliptical. Ocular ridge is wider (tr.) compared to palpebral lobe length (sag.) and the relative width (tr.) of the ocular ridge and palpebral lobe length (sag.) are sizerelated. Smaller specimens have wider (tr.) ocular ridge compared to palpebral lobe length (sag.) (Figure 5A-D), which contrasts larger specimens (Figure $5 \mathrm{E}-\mathrm{I}$ ). Glabella shape is variable: most specimens have a rectangular-shaped glabella that is expanded anteriorly in some larger specimens (Figure $5 \mathrm{G}-\mathrm{H}$ ). It is notable that some specimens only have a rectangular-shaped glabella without 


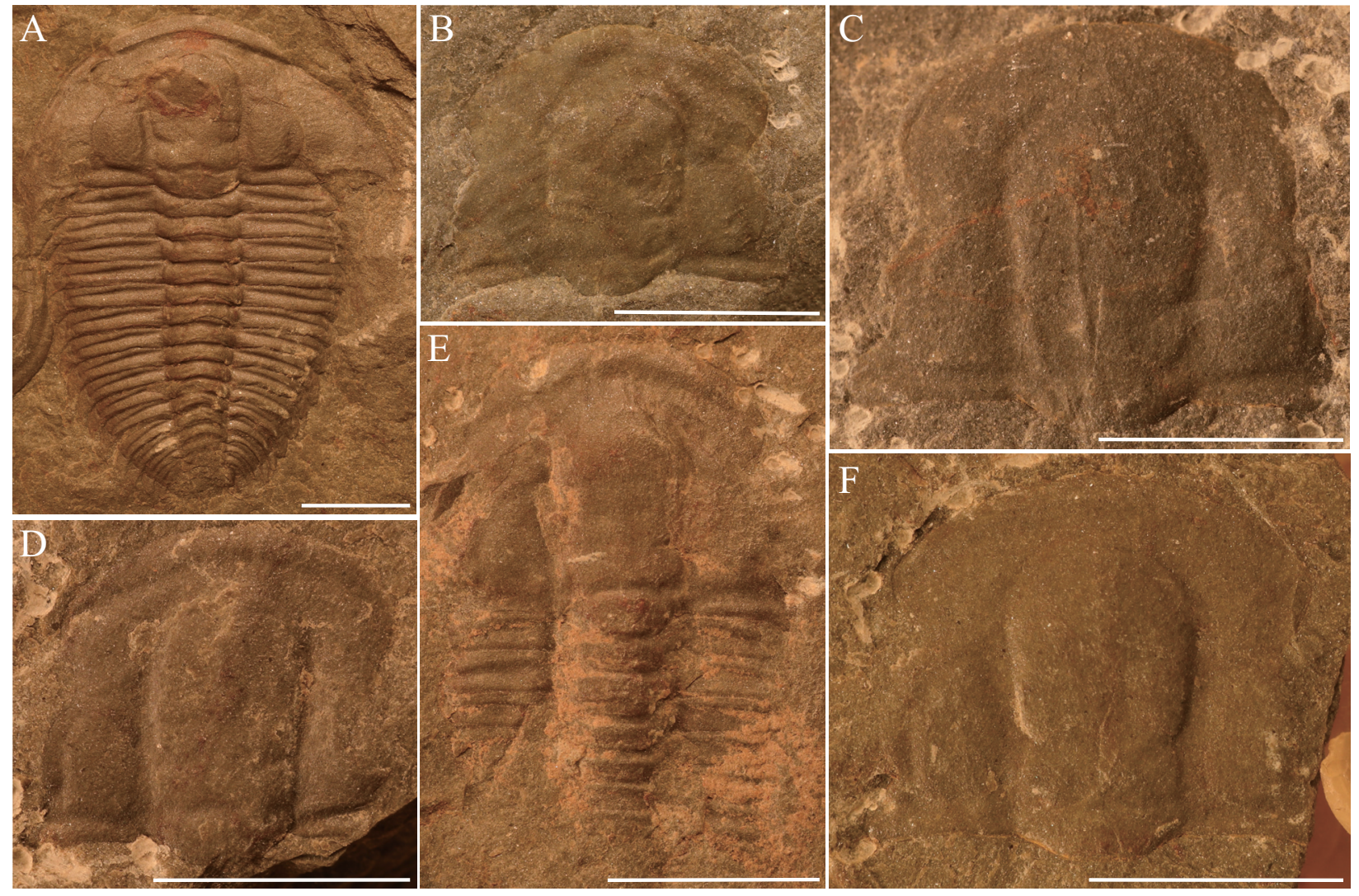

FIGURE 6. Articulated and disarticulated specimens of Megapalaeolenus deprati from the Huanglongqing Section. A. HLQ-39A. B. HLQ-19. C. HLQ-37. D. HLQ-50. E. HLQ-13. F. HLQ-33. Scale bars equal 5 mm.

the expanded anterior (Figure 5A, D), and some specimens have a subcylindrical glabella (Figure 5I). Three or four pairs of glabellar furrows present. Fixigena is wider (tr.) than the librigena. The postero-lateral projection is long (sag.) and narrow (tr.). Most specimens have 13 thoracic tergites with larger specimens displaying 14 or 15 tergites. Pleural lobe is slightly wider (tr.) than axial lobe. Semi-elliptic pygidium is divided into two parts by one transverse furrow. Its axial lobe is relatively wide (tr.) compared to its pleural lobe.

Remarks. The geometric morphometric results show that cranidia of Palaeolenus douvillei and $P$. "Iantenoisi" occupy the same region of morphospace. Palaeolenus douvillei therefore shows substantial variation where most studied specimens have 13 thoracic tergites, indicative of $P$. "lantenoisi", while large specimens have 14 or even 15 thoracic tergites, are indicative of $P$. douvillei (sensu Mansuy, 1912). Compared with Megapalaeolenus deprati, the palpebral lobes of $P$. douvillei are consistently shorter (sag.) or at most similar in length (tr.) to ocular ridges, with larger specimens having proportionally longer palpebral lobes than smaller specimens. The length (sag.) of the anterior border is variable and not size-related.

Genus MEGAPALAEOLENUS Chang, 1966

Type species. Megapalaeolenus deprati Mansuy, 1912 by original designation (Chang 1966).

Megapalaeolenus deprati (Mansuy, 1912) Figure 6

1912 Palaeolenus deprati Mansuy. Mansuy, p. 30, pl. 4, fig. 3a, b.

1941 Palaeolenus deprati Mansuy. Lu, p. 84, pl. 1, fig. 12a-c.

1965 Palaeolenus deprati Mansuy. Lu, Chang, Chu, Chien, and Hsiang, p. 83, pl. 12, fig. 10.

1966 Megapalaeolenus deprati Mansuy. Chang, p. 150

1978 Megapalaeolenus deprati Mansuy. Zhou and Lin, p. 148, pl. 24, figs. 5, 6.

1980 Megapalaeolenus deprati Mansuy. Chang, Lu, Chu, Chien, Lin, Zhou, Zhang, and Yuan, p. 232, pl. 72, figs. 2-5.

2007 Megapalaeolenus deprati Mansuy. Luo, Li, Hu, Fu, Hou, You, Pang, and Liu, p. 317, pl. 3, figs. 1-14. 
2008 Megapalaeolenus deprati Mansuy. Luo, Li, Hu, $\mathrm{Fu}$, Hou, Liu, Chen, Li, Pang, and Liu, p. 77, pl. 19, figs. 4-14.

2013 Megapalaeolenus deprati Mansuy. Hu, Zhu, Luo, Steiner, Zhao, Li, Liu, and Zhang, p. 101, figs. 125-129.

2014 Megapalaeolenus deprati Mansuy. Luo, Hu, Chen, Zhan, and Lu, p. 564, pl. 1, figs. 1-8; pl. 2, figs. 1-7.

Referred material. HLQ-3, HLQ-14, HLQ-19, HLQ-22, HLQ-33, HLQ-37, HLQ-39, HLQ-40, HLQ-46, HLQ-50.

Diagnosis. Megapalaeolenus with short (tr.) ocular ridges, long (exs.) palpebral lobes, subparallel to the axial furrow with a robust glabella that is expanded anteriorly, a relatively narrow (tr.) fixigena, more curved pleural spines and wider (tr.) pleural lobes.

Description. Body ovate, with a length (sag.) of 2$3 \mathrm{~cm}$. Cephalon half elliptic. Palpebral lobe consistently longer (exs.) than ocular ridge, subparallel to axial furrow. Glabella rounded and its anterior part expanded. The number of glabellar furrows is variable due to taphonomic alteration, but can be up to four. The fixigena is narrower (tr.) to equally wide compared to the librigena. The postero-lateral projection is relatively short (sag.) and wide (tr.). The number of thoracic tergites is 15 . The pleural lobe is pronouncedly wider (tr.) than axial lobe. The semi-elliptical pygidium is much smaller than the cephalon and is divided into two parts by one transverse furrow. The axial lobe of pygidium is relatively wide compared to the pleural lobe.

Remarks. The geometric morphometric results show that Megepalaeolenus deprati and Palaeolenus douvillei occupy different areas of morphospace. $M$. deprati can be differentiated from $P$. douvillei by more rounded glabella, longer (sag.) palpebral lobes, shorter (tr.) ocular ridges, and more developed posterolateral projections. Additionally, pleural spines of $M$. deprati are more curved and its pleural lobe is pronouncedly wider (tr.) than axial lobe.

\section{CONCLUSIONS}

The results of geometric morphometric analysis of 60 palaeolenid trilobites from the early Cambrian Wulongqing Formation show that the groups have been over-split and of the three speciesPalaeolenus douvillei, P. "lantenoisi" and Megapalaeolenus deprati-only $P$. douvillei and $M$. deprati are valid taxa. Palaeolenus "lantenoisi" is here considered a junior synonym of $P$. douvillei. Further studies of Chinese Cambrian trilobites may highlight an over-stated diversity and that such studies are imperative to thoroughly understanding diversity during the Cambrian explosion.

\section{ACKNOWLEDGMENTS}

This research is financially supported by the 973 project of the Ministry of Science and Technology of China (Grant 2013CB837100), the National Natural Science Foundation of China (Grant 41222014, 41172023, 41102012, 41272019, 41372021), the National Program for Support of Top-notch Young Professionals, the Ministry of Education of China, the Program of Introducing Talents of Discipline to Universities (P201102007, W20136100061), the Shaanxi Bureau of Science and Technology (FJ11366), the Young Talents of Northwest University, Program for New Century Excellent Talents in University (NCET-13-1008), Fundamental Research Funds for the Central Universities (2010ZY07, 2011YXL013, 2012097), the Strategic Priority Research Program of Chinese Academy of Sciences (XDB26010104), the 111 Project and the Ministry of Education of China for Chengjiang Scholars to Liu, J.N., and a University of New England Postdoctoral Fellowship (to R.D.C.B.). We thank J. Paterson, T. Park, F. Liu, F. Guo, H. Hu, M. Sun, and T. Dai for discussions and comments. L. Yan, Y. Wu, F. Chen and Y. Ding are thanked for collecting and managing specimens. We thank Y. Chen for training with software. Finally, we thank the comments of two anonymous reviewers that thoroughly improved the text.

\section{REFERENCES}

Abe, F.R. and Lieberman, B.S. 2012. Quantifying morphological change during an evolutionary radiation of Devonian trilobites. Paleobiology, 38:292-307. https://doi.org/10.1666/10047.1

Adams, D.C. and Otárola?Castillo, E. 2013. Geomorph: an R package for the collection and analysis of geometric morphometric shape data. Methods in Ecology and Evolution, 4:393399. https://doi.org/10.1111/2041-210X.12035 
Aytekin, M.A., Terzo, M., Rasmont, P., and Çağatay, N. 2007. Landmark based geometric morphometric analysis of wing shape in Sibiricobombus Vogt (Hymenoptera: Apidae: Bombus Latreille). Annales de la Société Entomologique de France, 43:95-102. https:// doi.org/10.1080/00379271.2007.10697499

Bicknell, R.D.C. 2019. Xiphosurid from the Upper Permian of Tasmania confirms Palaeozoic origin of Austrolimulidae. Palaeontologia Electronica, 22.3.62:1-13. https://doi.org/10.26879/ 1005 palaeo-electronica.org/content/2019/2758-a-permian-austrolimulid

Bicknell, R.D.C. and Pates, S. 2019. Xiphosurid from the Tournaisian (Carboniferous) of Scotland confirms deep origin of Limuloidea. Scientific Reports, 9:17102. https://doi.org/ 10.1038/s41598-019-53442-5

Bicknell, R.D.C., Collins, K.S., Crundwell, M., Hannah, M., Crampton, J.S., and Campione, N.E. 2018. Evolutionary transition in the late Neogene planktonic foraminiferal genus Truncorotalia. iScience, 8:295-303. https://doi.org/10.1016/j.isci.2018.09.013

Bicknell, R.D.C., Paterson, J.R., and Hopkins, M.J. 2019a. A trilobite cluster from the Silurian Rochester Shale of New York: predation patterns and possible defensive behavior. American Museum Novitates, 2019(3937): 1-16. https://doi.org/10.1206/3937.1

Bicknell, R.D.C., Žalohar, J., Miklavc, P., Celarc, B., Križnar, M., and Hitij, T. 2019b. A new limulid genus from the Strelovec Formation (Middle Triassic, Anisian) of northern Slovenia. Geological Magazine, 156:2017-2030. https://doi.org/10.1017/S0016756819000323

Chang, W.T. 1966. On the classification of Redlichiacea, with description of new families and new genera. Acta Palaeontologica Sinica, 14:135-184. [In Chinese with English abstract and systematic palaeontology]

Chang, W.T., Lu, Y.H., Chu, Z.L., Chien, Y.Y., Lin, H.L., Zhou, Z.Y., Zhang, S.G., and Yuan, J.L. 1980. Cambrian trilobite faunas of southwestern China. Palaeontologia Sinica, 159, New Series B, 16:1-497. [In Chinese]

Crônier, C., Budil, P., Fatka, O., and Laibl, L. 2015. Intraspecific bimodal variability in eye lenses of two Devonian trilobites. Paleobiology, 41:554-569. https://doi.org/10.1017/pab.2015.29

Ding, Y., Liu, J.N., and Chen, F.F. 2020. Ichnology, palaeoenvironment, and ecosystem dynamics of the Early Cambrian (Stage 4, Series 2) Guanshan Biota, South China. Geological Journal, 55:77-94. https://doi.org/10.1002/gj.3360

Esteve, J., Zhao, Y., and Peng, J. 2017. Morphological assessment of the Cambrian trilobites Oryctocephalus indicus (Reed 1910) from China and Oryctocephalus 'reticulatus' (Lermontova 1940) from Siberia. Lethaia, 50:175-193. https://doi.org/10.1111/let.12185

Fusco, G., Hughes, N.C., Webster, M., and Minelli, A. 2004. Exploring developmental modes in a fossil arthropod: growth and trunk segmentation of the trilobite Aulacopleura konincki. The American Naturalist, 163:167-183. https://doi.org/10.1086/381042

Gendry, D., Courville, P., Saucède, T., Laffont, R., and Paris, F. 2013. Contribution of morphometrics to the systematics of the Ordovician genus Neseuretus (Calymenidae, Trilobita) from the Armorican Massif, France. Journal of Paleontology, 87:456-471. https:// doi.org/10.1666/12-046.1

Hopkins, M.J. and Webster, M. 2009. Ontogeny and geographic variation of a new species of the corynexochine trilobite Zacanthopsis (Dyeran, Cambrian). Journal of Paleontology, 83:524547. https://doi.org/10.1666/08-102r.1

Hu, S.X., Zhu, M.Y., Steiner, M., Luo, H.L., Zhao, F.C, and Liu, Q. 2010. Biodiversity and taphonomy of the Early Cambrian Guanshan biota, eastern Yunnan. Science China Earth Sciences, 53:1765-1773. https://doi.org/10.1007/s11434-011-9968-5

Hu, S.X., Zhu, M.Y., Luo, H.L., Steiner, M., Zhao, F.C., Li, G.X., Liu, Q., and Zhang, Z.F. 2013. The Guanshan Biota. Yunnan Science and Technology Press, Kunming, China. [In Chinese with English abstract]

Hu, S.X., Zhu, M.Y., Zhao, F.C., and Steiner, M. 2017. A crown group priapulid from the early Cambrian Guanshan Lagerstätte. Geological Magazine, 154:1329-1333. https://doi.org/ $10.1017 / \mathrm{s} 001675681700019 x$

Hughes, N.C. 1991. Morphological plasticity and genetic flexibility in a Cambrian trilobite. Geology, 19:913-916. https://doi.org/10.1130/0091-7613(1991)019<0913:mpagfi>2.3.co;2

Hughes, N.C. 1994. Ontogeny, intraspecific variation, and systematics of the Late Cambrian trilobite Dikelocephalus. Smithsonian Contributions to Paleobiology, 79:1-89. https://doi.org/ 10.5479/si.00810266.79.1 
Hughes, N.C., Chapman, R.E., and Adrain, J.M. 1999. The stability of thoracic segmentation in trilobites: a case study in developmental and ecological constraints. Evolution and Development, 1:24-35. https://doi.org/10.1046/j.1525-142x.1999.99005.x

Hughes, N.C., Hong, P.S., Hou, J., and Fusco, G. 2017. The development of the Silurian trilobite Aulacopleura koninckii reconstructed by applying inferred growth and segmentation dynamics: a case study in paleo-evo-devo. Frontiers in Ecology and Evolution, 5:37. https:// doi.org/10.3389/fevo.2017.00037

Hupé, P. 1952. Contribution a l'étude du Cambrien inférieur et du Précambrien III de l'Anti-Atlas marocain. Notes et Mémoires de la Service géologique du Maroc, 103, Rabat, Morocco.

Laibl, L., Fatka, O., Budil, P., Ahlberg, P., Szabad, M., Vokáč, V., and Kozák, V. 2015. The ontogeny of Ellipsocephalus (Trilobita) and systematic position of Ellipsocephalidae. Alcheringa, 39: 477-487. https://doi.org/10.1080/03115518.2015.1034968

Lin, T.R. 2014. Application of cluster analysis to the taxonomy of palaeolenid trilobites, China-A new approach to the biozonay classification of the upper part of Tsanglangpu Formation of the Qiandongian Series in China. Acta Palaeontologica Sinica, 53:108-120. [In Chinese with English abstract]

Lin, T.R. and Peng, S.C. 2004. New material of Palaeolenus (trilobite, Cambrian) from the eastern Yangtze Gorge area, Western Hubei. Acta Palaeontologica Sinica, 43:32-42. [In Chinese with English abstract]

Lin, T.R. and Peng, S.C. 2009. Further discussion on the invalidity of Megapalaeolenus Chang, 1966. Acta Palaeontologica Sinica, 48:695-700. [In Chinese with English abstract]

Lin, T.R. and Peng, S.C. 2016. Review on the "New observations on the trilobite genus Megapalaeolenus" by Luo et al. (2014). Acta Palaeontologica Sinica, 55:269-279. [In Chinese with English abstract]

Liu, J.N., Ou, Q., Han, J., Zhang, Z.F., He, T.J., Yao, X.Y., Fu, D.J., and Shu, D.G. 2012. New occurrence of the Cambrian (Stage 4, Series 2) Guanshan Biota in Huize, Yunnan, South China. Bulletin of Geosciences, 87:125-132. https://doi.org/10.3140/bull.geosci.1229

Liu, J.N., Han, J., Li, J.S, Wu, Y.C., Peng, J., Qi, N., Yang Y.Y., and Li, J. 2016. New localities and palaeoscolecid worms from the Cambrian (Stage 4, Series 2) Guanshan Biota in Kunming, Yunnan, South China. Acta Geologica Sinica (English Edition), 90:1939-1945. https://doi.org/ 10.1111/1755-6724.13013

Lu, Y.H. 1941. Lower Cambrian stratigraphy and trilobite fauna of Kunming, Yunnan. Bulletin of the Geological Society of China, 21:71-90. https://doi.org/10.1111/j.17556724.1941.mp21001006.x

Lu, Y.H., Chang, W.T., Chu, C.L., Chien, Y.Y., and Hsiang, L.W. 1965. Trilobites of China. Science Press, Beijing. [In Chinese]

Luo, H.L., Li, Y., Hu, S.X., Fu, X.P., Hou, S.G., You, T., Pang, J.Y., and Liu, Q. 2007. On the genus Megapalaeolenus Chang, 1966. Acta Palaeontologica Sinica, 46:321. [In Chinese with English abstract]

Luo, H.L., Li, Y., Hu, S.X., Fu, X.P., Hou, S.G., Liu. X.Y., Chen, L.Z., Li, F.J., Pang, J.Y., and Liu, Q. 2008. Early Cambrian Malong Fauna and Guanshan Fauna from eastern Yunnan, China. Yunnan Science and Technology Press, Yunnan, China. [In Chinese with English summary]

Luo, H.L., Hu, S.X., Chen, Q.T., Zhan, D.Q., and Lu Y.X. 2014. New observations on the genus Megepalaeolenus. Acta Palaeontologica Sinica, 53:563-574. [In Chinese with English abstract]

MacLeod, N. 2001. Landmarks, localization, and the use of morphometrics in phylogenetic analysis, p. 197-233. In Adrain, J.M., Edgecombe, G.D., and Lieberman, B.S. (eds.), Fossils, Phylogeny, and Form. Springer, Boston. https://doi.org/10.1007/978-1-4615-0571-6_6

MacLeod, N. 2002. Phylogenetic signals in morphometric data, p. 100-138. In MacLeod, N. and Forey, P.L. (eds.), Morphology, Shape and Phylogeny. CRC Press, London. https://doi.org/ 10.1201/9780203165171.ch7

Mansuy, H. 1912. Étude géologique du Yun-Nan oriental, pt. 2, Paléontologie: Dévonien supérieur à Spirifer tenticulum et Rhynchonella huoti, de Sin-Ts' ouen et de Ta-Hi-Ti. Mémoires du Service Géologique de L'Indochine, 1:26-146. [In French]

Monti, D.S. 2018. Morphometrics of Leptoplastides marianus (Hoek) (Trilobita, Olenidae) from the Tremadocian of north-western Argentina: taxonomic implications. Journal of Systematic Palaeontology, 16:179-197. https://doi.org/10.1080/14772019.2017.1282992 
Park, T.Y., Han, Z., Bai, Z., and Choi, D.K. 2008. Two middle Cambrian trilobite genera, Cyclolorenzella Kobayashi, 1960 and Jiulongshania gen. nov., from Korea and China. Alcheringa, 32:247-269. https://doi.org/10.1080/03115510802096135

Pates, S., Bicknell, R.D., Daley, A.C., and Zamora, S. 2017. Quantitative analysis of repaired and unrepaired damage to trilobites from the Cambrian (Stage 4, Drumian) Iberian Chains, NE Spain. Palaios, 32:750-761. https://doi.org/10.2110/palo.2017.055

Webster, M. 2007. A Cambrian peak in morphological variation within trilobite species. Science, 317:499-502. https://doi.org/10.1126/science.1142964

Webster, M. 2011. The structure of cranidial shape variation in three early ptychoparioid trilobite species from the Dyeran-Delamaran (traditional "lower-middle" Cambrian) boundary interval of Nevada, USA. Journal of Paleontology, 85:179-225. https://doi.org/10.1666/10-075.1

Webster, M. 2015. Ontogeny and intraspecific variation of the early Cambrian trilobite Olenellus gilberti, with implications for olenelline phylogeny and macroevolutionary trends in phenotypic canalization. Journal of Systematic Palaeontology, 13:1-74. https://doi.org/ 10.1080/14772019.2013.852903

Webster, M. and Hughes, N.C. 1999. Compaction-related deformation in Cambrian olenelloid trilobites and its implications for fossil morphometry. Journal of Paleontology, 73:355-371. https://doi.org/10.1017/s0022336000027827

Webster, M. and Sheets, H.D. 2010. A practical introduction to landmark-based geometric morphometrics. The Paleontological Society Papers, 16:163-188. https://doi.org/10.1017/ s1089332600001868

Whittington, H.B., Chatterton, B.D.E., Speyer, S.E., Fortey, R.A., Owens, R.M., Chang, W.T., Dean, T., Jell, P.A., Laurie, J.R., Palmer, A.R., Repina, L.N., Rushton, A.W.A., Shergold, J.H., Clarkson, E.N.K., Wilmot, N.V., and Kelly, S.R.A. 1997. Trilobita. Treatise on Invertebrate Paleontology, Part O, Revised, Volume 1. Geological Society of America and University of Kansas Press, Boulder, Colorado, and Lawrence, Kansas.

Yi, D.R. 1988. Ontogeny of Palaeolenus lantenoisi (Trilobita). Acta Palaeontologica Sinica, 27:31-38. [In Chinese with English abstract]

Zelditch, M., Swiderske, D., and Sheets, D. 2004. Geometric Morphometrics for Biologists: a Primer. Elsevier Academic Press, San Diego, California. https://doi.org/10.1016/b978-0-12778460-1.x5000-5

Zhou, T.M. and Lin, T.R. 1978. Lower Cambrian trilobites, p. 143-154. In Stratigraphic Research Group of Yangtze Gorges, Hubei Bureau of Geology (ed.), The Stratigraphy and Palaeontology from Sinian to Permian, Eastern Yangtze Gorge. Geological Publishing House, Beijing, China. [In Chinese] 


\section{APPENDICES}

Appendices are combined and supplied in a zipped file for download at https://palaeo-electronica.org/content/2020/3030-revision-of-cambrian-trilobite-taxa.

\section{APPENDIX 1.}

TPS file of analyzed specimens.

\section{APPENDIX 2.}

CSV file of PCA results, specimen measurements, and additional data used in Figures 3 and 4. 